\title{
EVALUATION OF THE SPATIAL DISTRIBUTION AND EXTENT OF GULLY EROSION SITE USING HIGH RESOLUTION, REMOTE SENSING AND GIS IN ORLU AREA, EASTERN NIGERIA
}

\section{Chukwu, Kevin Ejike (Ph.D)}

Department of geography and Meteorology, Faculty of Environmental Science, Enugu State University of Science and technology (ESUT) Enugu State

Ewurum, Chukwuemeka, O.S.

Department of geography and Meteorology, Faculty of Environmental Science, Enugu State University of Science and technology (ESUT) Enugu State

This study seeks to evaluate the Spatial Distribution and Extent of Gully Erosion Site Using High Resolution, Remote Sensing and GIS in Orlu, Eastern Nigeria. The following objectives guide this study; assessment of spatial distribution and extent of gully erosion sites in the study area. The findings of the study reveals that: Analysis of satellite image covering the study area shows sixty six (66) spatially distributed gully sites were discovered and presented in the study. The spatial distribution of various soil properties were evaluated with satellite data, although often this is restricted to arid or vegetation cover, satellite data were applied for land use classification or the extraction of continuous measures of vegetation abundance and structure Soil erosion is recognized as one of the major causes of land degradation worldwide and a key impediment to environmental sustainability. It is a natural process of detachment, entrainment and transport of soil and materials through the action of erosive agents such as water, wind, gravity, and anthropogenic perturbations.

Keywords:Spatial Distribution, Gully Erosion Site Using High Resolution, Remote Sensing and GIS

\section{INTRODUCTION}

The growth of human population during the last century in combination with increasingly consumption patterns is putting a strong pressure on natural resources upon which man depends for survival (Cohen, 1995; Ehrilich, 1993; Ehrilich, 1993; and Daily, 1993; Meyer and Turner, 1992). Global concern about the consequence of human activities on the environment is therefore on the increase. Worldwide, effort is being made to mitigate the negative impacts of our intervention and to obtain a situation in which human utilization of natural resources is in equilibrium with their long-term ecological functions (Hannam and Boer, 2001; United Nations, 2002).

The ideal situation for the earth and mankind would be a sustainable system in which ecological and production functions are in balance and environmentally sustained. However, at the global level this situation is far from being realized, and is manifest in wide ranging environmental issues such as melting of ice sheets (Bindschadler, 2006) large-scale river flooding (Kundzewicz, 2005; Ulbrich, 2005; Brucher, 2005; Graczyk, Kruger, 2005; Leckebusch, 2005; Menzel, 2005; Pinskwar, 2005; Radziejewski, 2005 and Szwed, 2005), decline of biodiversity and accelerated soil erosion(Dirzo and Raven, 2003). 
Soil erosion is recognized as one of the major causes of land degradation worldwide (Valentin et al., 2005) and a key impediment to environmental sustainability (Lal, 2001). It is a natural process of detachment, entrainment and transport of soil and materials through the action of erosive agents such as water, wind, gravity, and anthropogenic perturbations. At geological time-scales there is a balance between erosion and soil formation (Tricart and KiwietdeJonge, 1992), but at many locations worldwide, disequilibrium currently exists between these two processes. This disequilibrium is called accelerated soil erosion and is principally caused by anthropogenic land use changes like deforestation and agricultural practices (Ofomata, 1982).

At the global scale, soil erosion by water is the most important land degradation problem (Eswaran, 2001; Lal, 2001; and Reich, 2001). It generates strong environmental impacts and high economic costs by its on-site effects on agricultural production and off-sites on infrastructure and water quality (Ananda and Herath, 2003; Lal, 1998; Pimentel et al., 1995). To mitigate these effects and reduce soil erosion, soil and water conservation strategies are required at different spatial and temporal scales (Morgan, 2005).

Spatial information on the importance of erosion at different scales is necessary for effective strategies and prioritizing conservation efforts. The interplay of environmental factors such as climate (rainfall, wind), soil type, topography, extent of vegetal cover as well as land-use activities are determinants of the type and magnitude of soil erosion.

In the past, comprehensive analysis of gullies has often been neglected by the scientific community. For example, a review by Casali et al (2009) shows that less than $10 \%$ of soil erosion studies around the world address gullies directly. However, in order to develop strategies to control, prevent and rehabilitate gullies, the spatial extent of the problem has to be established and monitored (Le Roux et al., 2007; Kakembo et al., 2009).

\subsection{Statement of the Research Problem}

The acquisition of high resolution topographic data is key to many studies in environmental sciences. For example mapping studies requiring data at high temporal (hourly, daily), and large spatial $(<5 \mathrm{kmsq})$ scales, traditional surveying methods are often costly and time consuming. Recent advances in technology have shown that the advent of digital Photogrammetry is a viable means of obtaining such high resolution topographic data (Smith et al., 2009; Rosnell and Honavaara, 2012; Fonstad, 2013; Dietrich, Couville, Jensen,Carbonneau, 2013). Consequently, the development and increased affordability of Unmanned Aerial Vehicles (UAVs) as a novel platform with which to collect the low-level aerial photographs needed for such Photogrammetric work, has seen a rapid increase in their usage in Geomophological studies (Lejot et al., 2007; Hugenholtz et al., 2013).

The technology of using high resolution imageries obtained from satellites in gully erosion study being a new development is yet to be exploited in Nigeria. With this technology, there is therefore an urgent need to determine the spatial pattern of soil erosion and also quantitatively determine the amount of soil loss resulting from soil erosion in the study area.

Soil loss is a grave concern and it is a world-wide problem. Soil degradation is a broader term for a decline in soil quality encompassing the deterioration in physical, chemical and biological attributers of the soil, which may be enhanced by, among other things; accelerated gully erosion (Eaton, 1996).Erosion by water is a primary agent of soil degradation at a global scale, affecting 1,094m hectares or roughly $56 \%$ of the land (Oldeman et al., 1991). This renders about 20 million hectares of crop land uncultivable annually according to estimates by (Elirehema, 2001). In general, Gully erosion is widely considered to be a serious threat to the long-term viability of agriculture in many parts of the world (El-Swaify et al., 1985). 


\subsection{Research Questions}

The study seeks to address the following research questions;

1. What is the distribution and spatial extent of gully sites in the study area?

\subsection{Aim and Objectives of the Study}

The aim of the study is to Evaluate Spatial Distribution and extent of Gully Erosion site in Orlu Using High Resolution, Remote Sensing and GIS. The objectives used in achieving the aim were;

1. Assessment of spatial distribution and extent of gully erosion sites in the study area.

\subsection{Research Hypotheses}

The hypotheses to be tested in this study are;

\section{Hypothesis (Ho)}

Ho: There is no significant difference in the extent of spatial distribution of gully erosion in the study area when compared to satellite imageries of 2007 and 2017.

\section{REVIEW OF RELATED LITERATURE \\ 2.1 Conceptual Issues}

Soil erosion is the physical removal of surface material by wind, moving ice or water (Agu,1994).The process of soil erosion involves detachment of sediments from the soil mass, transportation primarily by flowing water or wind and the eventual deposition of sediments (Ofomata, 1985)and (Lal, 1990). Soil erosion is a natural geomorphic process occurring continually over the earth's surface (Saha, 2004). Excessive erosion constitute many problems, such as receiving water sedimentation, ecosystem damage and outright loss of soil which could result to partial or complete loss of its productive capacity.

Eze, (2002), identifies soil erosion as the physical removal of soil particles including the fine element of plant nutrients from the land surface for deposition at lower terrains by water, wind and glaciers. (Ofomata, 1985) regarded soil erosion as merely a geomorphologic process, whereby the surface layer of weathered rock including plant nutrients are washed and carried away by agents of denudation. Finally, Adeniji, (1990), defines soil erosion as the detachment, entrainment and transportation of soil by one or more of such agents as gravity, ice mass, raindrops, running water and wind with or without the interference of man (anthropogenic).

Drawing from the above definitions, soil erosion is a three-stage process, this involves:
(1) Detachment
(2) Entrainment
(3) Transport, and
(4) Deposition of soil

\subsection{Types of Soil Erosion:}

Four soil erosion types have been identified by Engels and Machielsen (1988) they include sheet erosion, splash erosion, rill erosion and gully erosion.

\subsection{Factors of Soil Erosion}

Soil erosion generally is caused by several factors working simultaneously or individually to detach transports and deposit soil particles in different place other than where they were formed. The effects of this phenomenon are deep cuttings and ravine which dissect the entire land surface (Igwe, 2012). 
Earth scientists have established that a number of environmental factors as well as pedological parameters influence the extent of soil erosion globally. These factors are perhaps guided by human activities known as anthropogenic factors.

Igwe (1994) noted that the anthropogenic factors are mainly technical factors comprising mainly of land use and tillage methods, the choice and distribution of cultures and the nature of agro-technology. Giordano, et al (1991), showed that in the Northern hemisphere and many countries of Europe, among the factors that encourage soil erosion are vegetation clearance, intensive harvesting and over-grazing leaving the soil bare. Other factors are soil compaction caused by heavy machinery which reduces the infiltration capacity of the soil and thus promoting excessive water runoff and soil erosion.

Lal, (2001), Renard et al.,(1997), Igwe et al.,(1999),recognized the biophysical factors that regulate erosion processes to include topography/relief, climate (rainfall), soil, terrain and ground cover factors as being the main agents that determine the extent of soil erosion hazard. The importance of each individual factor is not always the same, but depends on regional characteristics, the erosion process under consideration, and spatial and temporal scale studied.

For purpose of this review, factors of soil erosion will be analyzed under the following headings according to Costick, (1996), Namely topography, influence of climatic factor (rainfall) erosivity, influence of vegetation, influence of geology, influence of soil factors (erodibility) and anthropogenic influence (land use).

\subsection{Conceptual and Theoretical Framework:}

According to the Canadian Centre for Remote Sensing (2013) remote sensing is the science of acquiring information about the Earth's surface without actually being in contact with it. This is done by sensing and recording reflected or emitted energy and processing, analyzing, and applying that information. However, modern Remote Sensing means acquiring information about earth's land and water surfaces by using reflected or emitted electromagnetic energy.

Remote sensing includes all methods of obtaining pictures or other forms of electromagnetic records of Earth's surface from a distance, and the treatment and processing of the pictures data (White, 1977). Remote sensing then in the widest sense is concerned with detecting and recording electromagnetic radiation from the target area in the field of view of the sensor instrument. This radiation may have originated directly from separate components of the target area, it may be solar energy reflected from them; or it may be reflections of energy transmitted to the target area from the sensor itself.

According to American Society for Photogrammetry and Remote Sensing (1990) imagery is acquired with a sensor other than (or in addition to) a conventional camera through which a scene is recorded, such as electronic scanning, using radiations outside the normal visual range of the film and camera- microwave, radar, thermal, infra-red, ultra violet, as well as multispectral, special techniques are applied to process and interpret remote sensing imagery for the purpose of producing conventional maps, thematic maps, resource surveys, etc. in the fields of agriculture, archaeology, forestry, geography, geology etc.

\subsection{Historical Development of Remote Sensing}

The knowledge about the history of remote sensing is necessary for better understanding of the subject and its scope and future development particularly for the welfare of human society. According to (Bijker, 1997), the historical development of remote sensing can be broadly be divided into six phases namely, Phase I (Up till 1920), phase II (1920-1945) Development of platforms and Sensors, phase III (1945-1950) Development of Teaching and 
Training, phase IV (1950-1960) Development of Instruments for Interpretation, phase V (1960-1985).

Significant phase, phase VI (1985-unwards) Recent Development phase, in this period, remote sensing technique has been improved in two ways, firstly, there have been developments of sensors which can use infrared and microwave spectrum other than visible spectrum to get information about earth's surface. Secondly, there have been very important advances with respect to the platforms in which sensors are mounted (Kramer, 2002), opined that satellites have been launched for specific purpose and with specific capability. The ground resolution is continuously increasing till date. Hence, interpretation and mapping is becoming very easy and accurate. The European Radar satellite (ERS-1) launched in 1991 opened the gate way for systematic global observation in the microwave region. The French satellite "SPOT" is producing imagery to enable three dimensional views under stereoscope. The satellite "IKONOS" launched on $24^{\text {th }}$ September, 1999 has one (1) meter resolution in panchromatic and (4) meters in multi-spectral band, so that the users are assured continually of satellite data.

In remote sensing, the term resolution is used to represent the resolving power, which includes not only the capability to identify the presence of two objects, but also their properties. In qualitative terms, the resolution is the amount of details that can be observed in an image.

\subsection{Empirical Review}

The spatial distribution of various soil properties may be evaluated with satellite data, although often this is restricted to arid or vegetation cover, satellite data can be applied for land use classification or the extraction of continuous measures of vegetation abundance and structure (Hall et al., 1995). Erosion factors are not static, but change with time. The most dynamic factors are rainfall and or crusting. The temporal variability of erosion factors needs to be accounted for in satellite- different moments of the year using multi-temporal satellite imagery (De Jong et al., 1999). A second option is to ascertain that a mono-temporal satellite image represents conditions of the factor under study at the moment of highest erosion risk; Image timing can thus be relevant for obtaining accurate spatial erosion patterns, although rationales for image section are often not clearly defined in erosion studies.

Despite the vast amount of existing studies on the remote sensing of variable that are of importance for erosion studies, little work has been done on developing methodologies for mapping soil erosion based specifically on these remotely-sensed variables. In most cases, an erosion model such as the USLE, developed for small erosion plots $(1.8$ by $22.1 \mathrm{~m})$ in the eastern United States, is simply applied to larger scales and different regions, while satellite data merely provides vegetation information as an input (Kim et al., 2005; Liu et al., 2004; Metternicht, $1996 \mathrm{Lu}$ et al., 1995b; CORINE, 1992). However, these studies were all performed for semi-arid regions and rely on specific observables in these environments. Erosion mapping methodologies based on remotely-sensed variables could however also be valuable for more humid environments. Local experts may assist in defining suitable methodologies for region-specific erosion mapping through defining the locally-important variables which can explain the spatial differences of erosion and can be obtained from satellite data.

\subsection{Studies on Soil Erosion in Nigeria:}

There is no part of the country that is free from at least one of these forms of erosion. (Obiefuna and Emebiri 1996; Osuji, 1996; Onu, 2003). According to (Obiefuna and Emebiri, (1996); there is more than 50 percent of the estimated 30 million tons annual soil loss in Nigeria through erosion. 
Gully erosion types are the more obvious forms of erosion in Nigeria, mainly because of the remarkable impression they have on the landscape (Nwafor, 2006). The highest concentration of severe gully erosion in Nigeria is found in Eastern parts of Nigeria were gullies of over $120 \mathrm{~m}$ in depth and $100 \mathrm{~m}$ in width are common.

Adinna,(2001); asserts that considerable part of Akwa Ibom, Imo, Abia, Anambra and Enugu states are affected with gullies especially on the east facing scrap faces while sheet erosion with intermittent gullies are common in the Northern parts of Delta and Auchi Edo states. In Western part of Nigeria, soil erosions are great problems. Several accounts have revealed the severity of the problem in Ondo, Ogun and Oyo states (Jeje, 1978).

Other examples, but on a much smaller scale, exist on the Jos plateau, especially in Heipang, around Zaria and Ankpa in Kogi State.

Much more pernicious and highly detrimental to agriculture is sheet erosion which often goes on unnoticed due to its gradual, constant and uniform action but which finally results in a complete removal of arable parts of the soil. Through this action of sheet erosion, the topsoil is gradually swept clear of its finer elements and plant nutrients, and only coarse, infertile materials are left behind.

Wind erosion occurs more generally and more frequently in the extreme northern parts of the country, but is limited in both time and space in other parts. Some of the materials removed by the wind reached the southern parts of the country by way of dust-laden winds (the North Easterly Trades especially during the period of the harmattan.

\section{THE RESEARCH METHOD}

\subsection{Research Design:}

The study employs the survey research design. Data was collected mainly from the field for gully extent and distribution analysis study.

\subsection{Data Collection:}

\subsubsection{Study Population:}

The populations for the study consist of all active gully sites identified within the study area as identified on the satellite images.

\subsubsection{Sampling:}

In view of the scattered nature of the data required and the need to reduce the volume of data, sampling was employed for the identification and selection of data.

For these, twenty one study locations shall be randomly selected for the study. This figure was arrived at by purposefully selecting three active gully sites from each of the three local government areas within the study area. The justification for this is that since the study involves assessment of the impacts of gully erosion in the study area, the use of the most active gully sites would the delimitation of our investigations within the confines of every location.

\subsection{Data Needs}

Field data was used for the study. The field data that was used, include those derived as input into erosion model such as rainfall, soil erodibility, slope steepness, conservation support practice factors.

These field data, serves as input parameters into erosion model for the computation of soil loss and prediction of the impacts of gully erosion in the environment of the study. 


\section{Results and Discussion of Findings}

\subsection{Spatial Distribution and extent of gully Site in Study Area}

Areas of potential gully were mapped using high resolution satellite imagery and Field Coordinate. The input parameter for the Hazard map were vegetation /land use map, geology map, rainfall map, relief map (slope), road map population density, and soil map. Fifty eight gully erosion sites were identified in the study area and coordinated during field work. From the processed high resolution satellite imagery, twenty additional gully sites were located (Figure.5.1). Further verification (ground truthing) confirmed that those points were actually gully erosion sites. The GPS coordinates of the gully sites were recorded in tabular form and used as index to the gully map (Appendix 1).

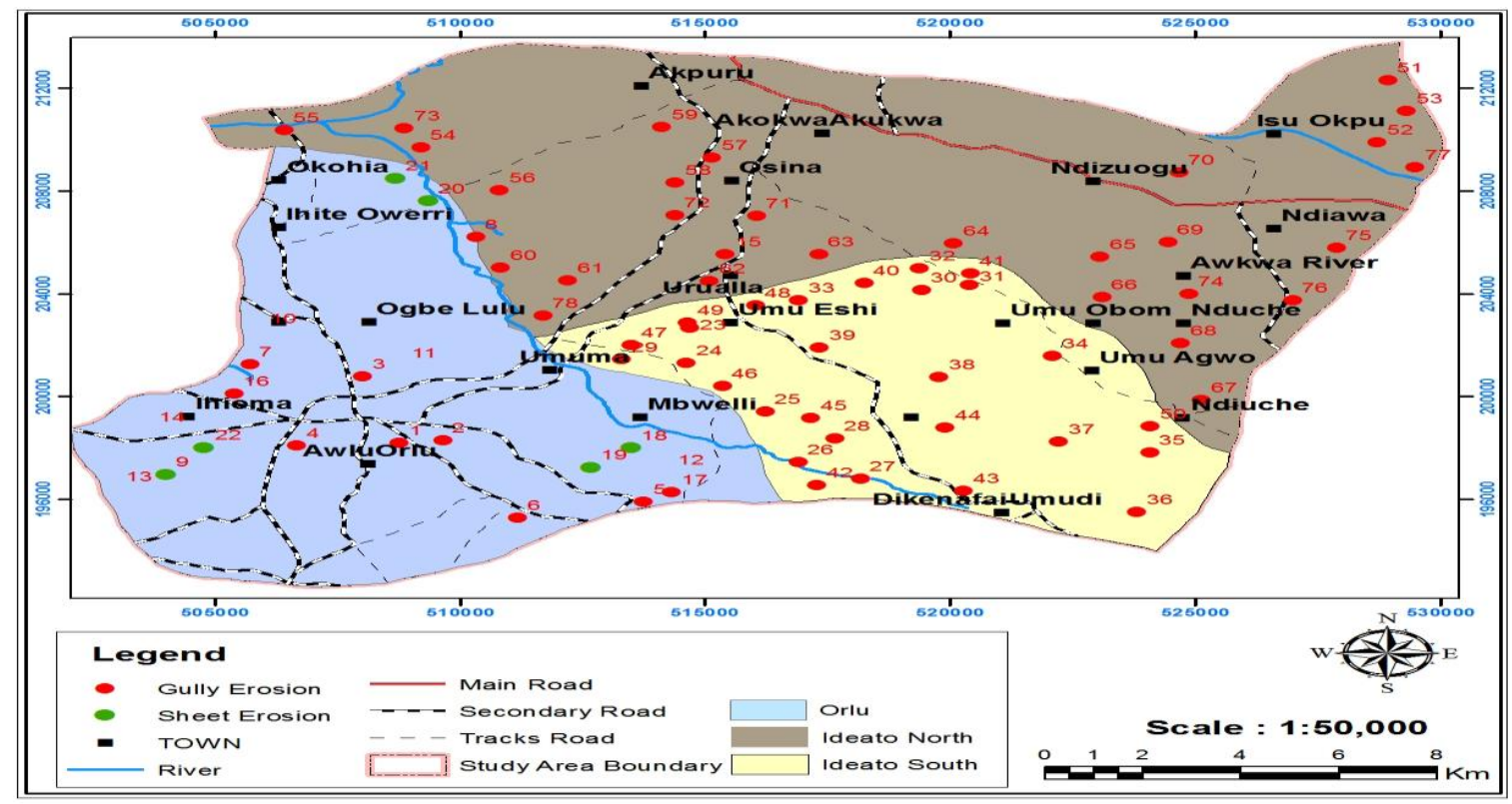

Figure 5.1: Spatial Distribution of the Gully Erosion in the Study Area.

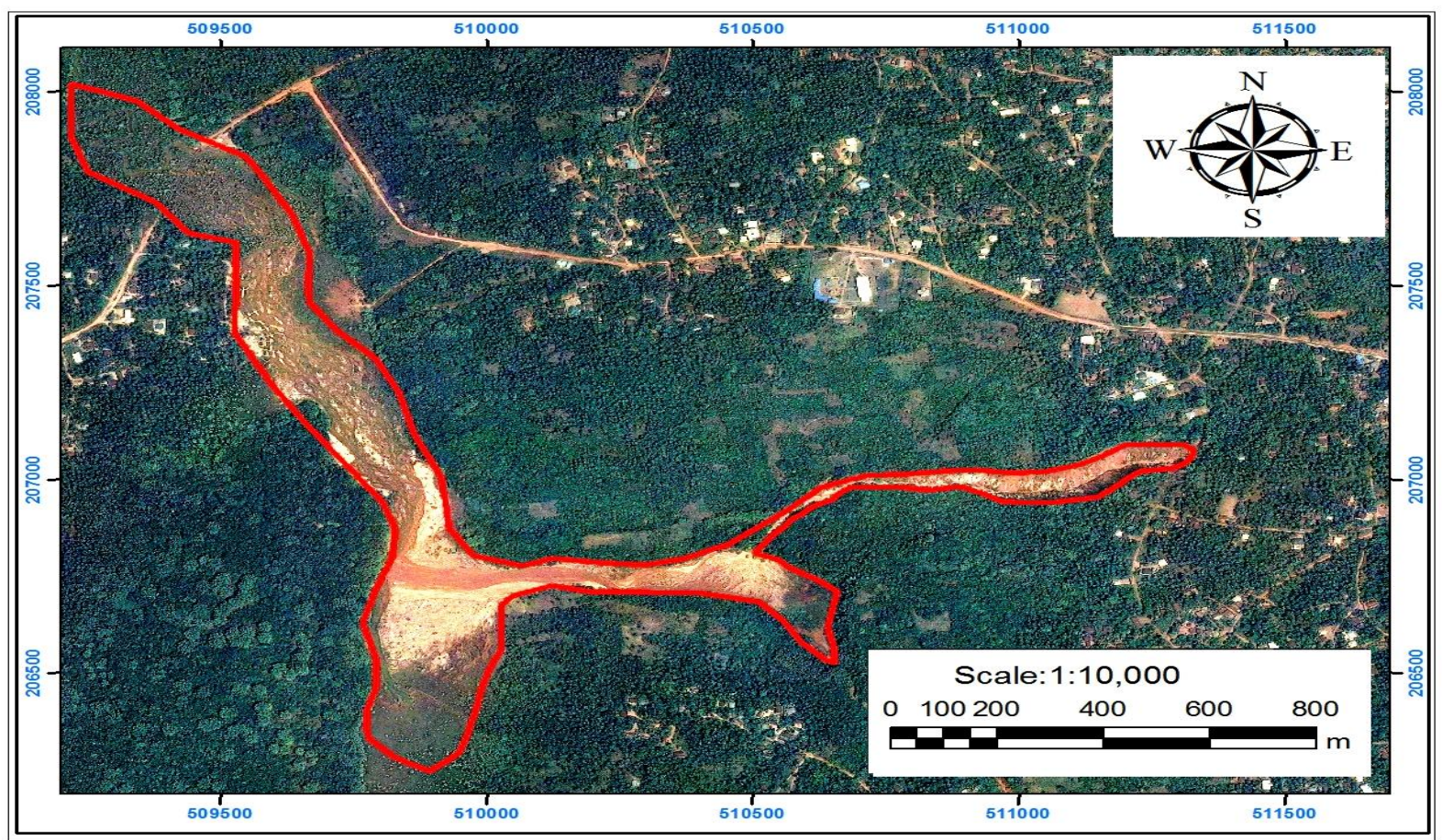

Figure 5.2: High Resolution image of Urualla Gully at Girls Sec. School at Akokwa (Ideato North LGA) 


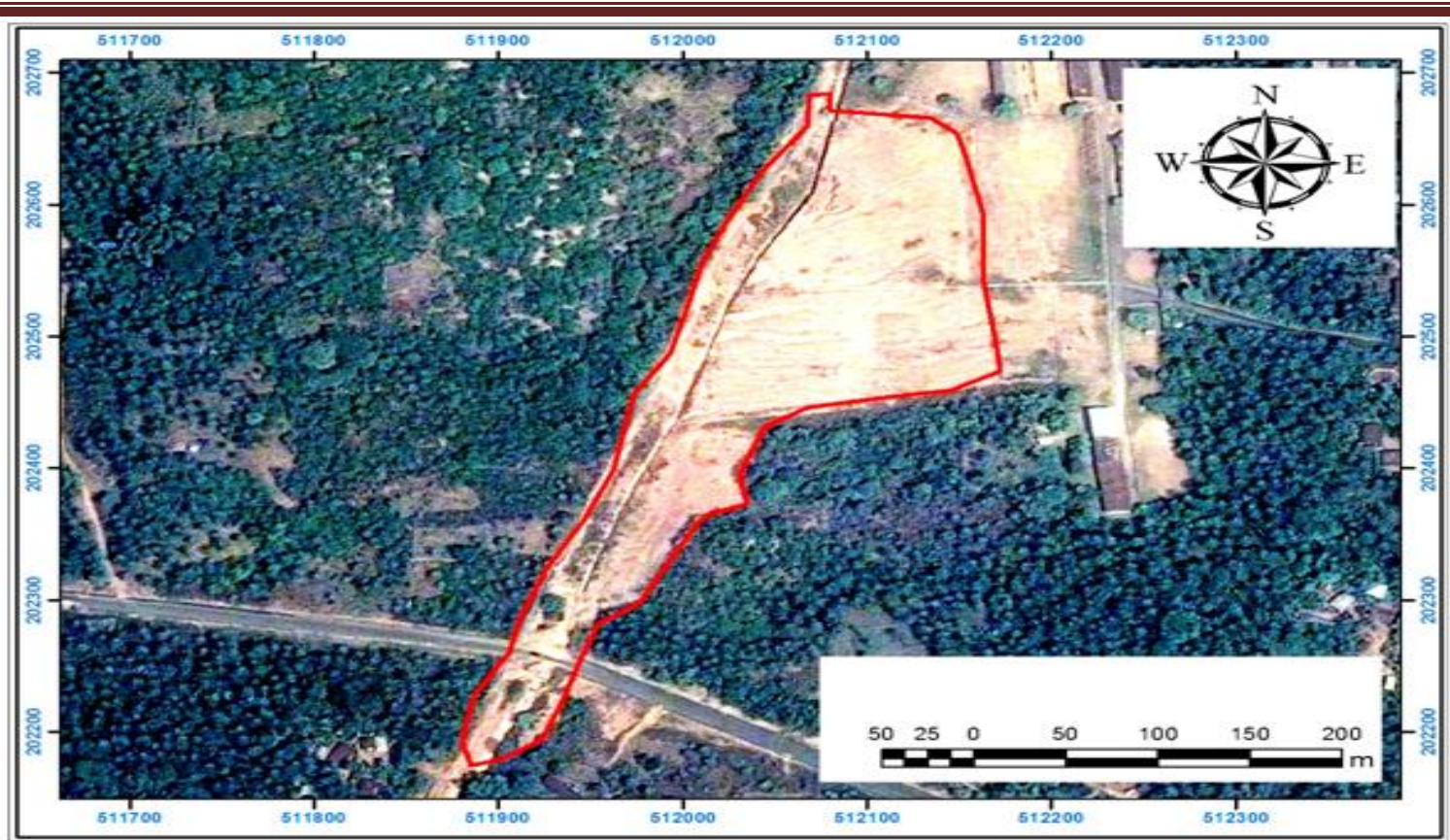

Figure 5.3: High resolution image of Osina Seminary road Gully Erosion (Ideato South LGA)

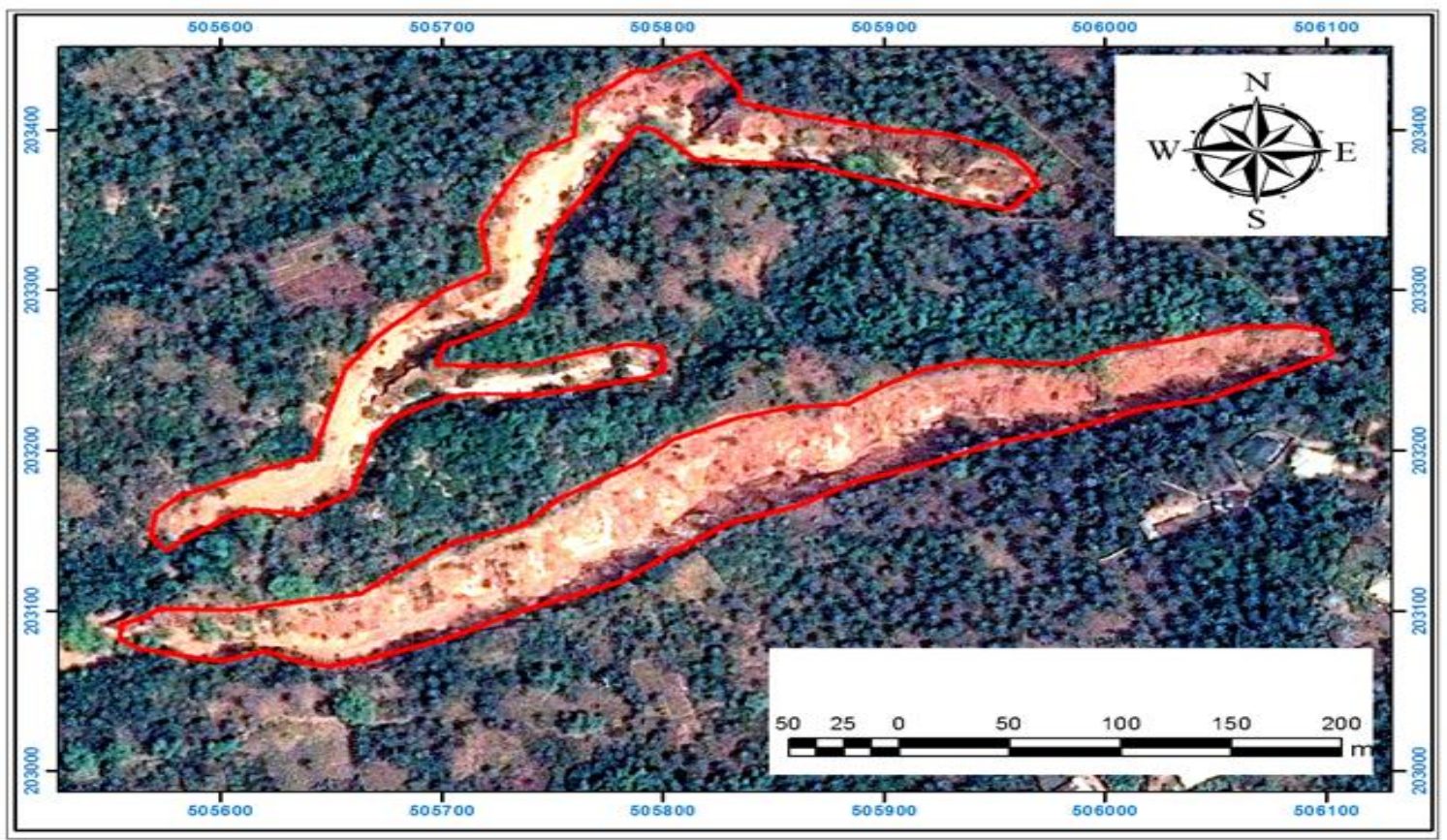

Figure 5.4: High resolution image of Umuezeala road Gully Erosion (Orlu LGA)

\section{Summary of Findings}

Soil erosion is a worldwide phenomenon which ravages large areas of land particularly in high rainfall or windy locations (Poesen et al. 1996). The application of GIS in gully erosion study cannot be over emphasized (Nwilo et al. 2011). The results of the study indicate that the amount of soil loss in the study area is high. This is due to high rainfall, increased population and livestock growth leading to shortages of farm land for the sustenance of household livelihood, continuous plow of the same land without fallow, complete ruining of soil conservation structures and lack of perception to participate in soil conservation interventions for at least the last decades in the study areas in particular. 


\section{Recommendations}

Considering the findings and observations made by this study, the following recommendations are therefore put forward;

(i) The use of remote sensing and GIS technique gully erosion mapping and monitoring will help to quickly identify gully erosion risk areas that cannot be accessed and also help to

Estimate rapidly the extent of areas affected by the researcher.

(ii) This study should be extended to all the local government areas of the state and by Extension the south eastern states, to enable continuous data gathering for gully erosion monitoring and assessment.

\section{Conclusions}

This study carried out assessment of gully erosion impacts in Orlu and its environs in order to help in the control and management of gully sites in the area. Remote Sensing and GIS technique were applied in this research to carry out mapping of gully affected area in Orlu, Ideato south and Ideato north local government areas using the Revised Universal Soil loss equation (RUSLE). Analysis of satellite image covering the study area shows sixty six (66) spatially distributed gully sites were discovered and presented in figure 5.1

\section{References}

1. Adeniji, F. A 1990. Soil Erosion Research Tools "Analytical or Emperical Models" Proceedings of the National Seminar on Erosion Ravages in South-Eastern Nigeria Held at Federal University of Technology Owerri May $29-31$.

2. Adinna, E.N. (2001): Environmental Hazard and Management, Enugu: Snaap Press Limited.

3. Agu, A.N. (1994). "Problems of soil erosion: causes and solutions." Symposium, on Environment and Social Harmony:A symposium jointly organized by the British Council and the Faculty of Environmental Sciences, ESUT, Enugu. 3rd May.

4. American Society for Photogrammetry and Remote Sensing (1990): www.asprs.org. October 2018.

5. Ananda J. and Herath G. 2003. Soil erosion in developing countries: a socio-economic appraisal. Journal Environmental Management. 68 (4); 343-353.

6. Bindschadler R. (2006). Hitting the ice sheets where it hurts. Science 311 (5768); 1720 1721.

7. Bijker, W. (1997). Radar for rain forest: a Mornitoring system for Land cover change in Colombian Amazon. Ph.d thesis, ITC, Enschede, the Netherlands. 373.

8. Casali, J., Gimenez R, and Bennett S. (2009). "Gully erosion processes: monitoring and modelling”, Earth Surface Processes and Landforms, 34: 1839 - 1840.

9. Cohen, J. E. 1995. Population growth and earth's human carrying capacity. Science 269 (5222): 34 1-346.

10. Costick, L. A. (1996).Indexing Curent Watershed Conditions Using Remote Sensing and GIS. Department of Land, Air, and Water Resources and Sierra Nevada Ecosystem Project, University of California, Davis. California, USA.

11. De Jong, S. M, Paracchini M. L, Bertolo F, Folving S, Megier I, and De Roo A. P. J. (1999). Regional assessment of soil erosion using the distributed model SEMMED and remotely sensed data. Catena 37 (3-4); 291-308.

12. Dirzo R, and Raven PH. (2003). Global state of biodiversity and loss. Annual Review of Environment and Resources 28: 137-167.

13. Eaton, D. (1996). The economics of soil erosion: A model of farm decision making. Environmental economics programme discussion paper, DP 96-01. 
14. Elirehema, Y. S. (2001). Soil Water erosion modeling in Selected Watersheds in Southern Spain. IFA; ITC, Enschede. Quoted in Yazidhi, B. (2003). A comparative Study of Soil Erosion Modeling in Lom Kao-Phetchabun, Thailand. Unpublished M.Sc. Thesis. ITC, The Netherlands.

15. El-Swaify et al. (1985).Soil Erosion and Conservation.Soil Conservation Society of America, Ankeny, Iowa.Quoted in Eaton, D. (1996). The Economics of Soil Erosion: A Model of farm Decision-making. Environmental Economics Programme Discussion Paper, DP 96 - 01, The Hague, The Netherlands, P. 52.

16. Eswaran H, Lal R, and Reich P. F. 2001. Land degradation: an overview. in: Bridges EM, Hannam 10, Oldeman LR, Penning de Vries FWT, Scherr Si, and Sombatpanit S (Editors), Response to land degradation. Science Publishers Inc., Enfield, NH, USA.

17. Eze, H.I. (2002): Impact of Soil Erosion on Bio-physical and Socio-Economic Resources in the Upper Ebonyi River Basin of Enugu State. Unpublished Ph.D Thesis, Department of Geography and Meteorology Enugu State University, Enugu Nigeria.

18. Fonstad M. A, Dietrich J. T, Couville B. C, Jensen J. L, Carbonneau P. E, 2013. Topographic structure from motion: a new development from photogrammetric measurement. Earth Surface Processes and Landforms 38: 421 - 430.

19. Hall F.G, Townshend JR, and Engman ET. (1995). Status of remote-sensing algorithms for estimation of land-surface state parameters. Remote Sensing of Environment 51(1): 138-156.

20. Hugenholtz C. H, Whitehead K, Brown O. W, Barchyn T. E, Moorman B. J, LeClair A, Riddell K, Hamilton T . (2013). Geomophological mapping with a small unmanned aircraft system (SUAS). Feature detection and accuracy assessment of a photogram metrically-derived digital terrain model. Geomophology 194: 16 - 24.

21. Igwe, C. A. (1994): The applicability of SLEMSA and USLE erosion models on soils of Southeastern Nigeria. PhD thesis University of Nigeria Nsukka.

22. Kakembo, V., Xanga, W. W. and Rowntree, K (2009), "Topographic thresholds in gully development on the hillslopes of communal areas in Ngqushwa Local Municipality, Eastern Cape, South Africa, Geomorphology, 110, (3-4): 188 - 194.

23. Kim J B, Saunders P, and Finn J T. (2005). Rapid assessment of soil erosion in the Rio Lempa Basin, Central America, using the universal soil loss equation and geographic information systems. Environmental Management 36 (6): 872-885.

24. Kramer, L. A. \& Meyer, L. D. (1969) Small amount of surface mulch reduce soil erosion and runoff velocity. Transaction of the American Society for Agriculture and Engineering. 12, 638, 645.

25. Kundzewicz Z W, Ulbrich U, Bru?cher T, Graczyk D, Kru?ger A, Leckebusch GC, Menzel L, Pin?skwar 1, Radziejewski M, and Szwed M. (2005). Summer floods in Central Europe - Climate change track? Natural Hazards 36 (1-2): 165-189.

26. Lejot J, Delacourt C, Piegay H, Fourier T, Tremelo M. L, Allemand P. (2007).

27. Very high spatial resolution imagery for channel bathymetry and topography from an unmanned mapping controlled platform. Earth Surface Processes and Landforms 32: $1705-1725$.

28. Le Roux, J .J. Newby, T. S. and Sumner, P. D. (2007). 'Monitoring soil erosion in South Africa at a regional scale: review and recommendations', South African Journal of Science, 103: 329 - 335.

29. Morgan R P C. (1974): Estimating regional variations in soil Erosion Hazard in Peninsular Malaysia, Malayan Nature Journal, (28) 94-106.

30. Nwafor, J.C. (2006): Environmental Impact Assessment for Sustainable Development, the Nigerian Paspective. Enugu: El demak Publication. 
31. Nwilo, P. C., Olayinka, D. N., Uwadiegwu, I., Adzandeh, A. E., (2011). An Assessment and mapping of Gully Erosion Hazards in Abia State: A GIS Approach: Journal of Sustainable Development (5).

32. Obiefuna, J.C and Emebiri L.C. (1996). "Tree crops Farming System for Erosion Control in Southeastern Nigeria" In: Management and Control of Erosion in Agric Practices: A Handbook, Njoku, J.E and Ozara N. (Edited). Institute of Erosion Research, Federal University of Technology Owerri. Nigeria.

33. Ofomata, G. E. K. (1966). Quelques observations sur 1' eboulement d' Awgu, Nigeria Oriental, Bulletin De l' IFAN. Series A, (28) 433-443.

34. Ofomata G.E.K (1985): Soil erosion in Nigeria: The views of a geomophologist. Inaugural Lecture Series. No 7 University of Nigeria Nsukka: 43.

35. Olderman et al.1991. World map on the status of human-induced soil degradation: An explanatory note ISRIC Wageningen, p. 41. Quoted in Hoyos, N. 2005. Spatial modeling of soil erosion potential in a tropical watershed of the Colombian Andes. Department of Geography, University of Florida, USA.

36. Renard, K. G., Foster, G. R., Weesies, G. A., Mc Cool, D. K., and Yoder, D. C. (1997).Predicting Soil Erosion by Water: A guide to Conservation Planning with the Revised Universal Soil Loss Equation. U.S. Department of Agriculture, Agriculture Handbook, 703, 384-385.

37. Rosnell T, Honkavaara E., (2012). Point cloud generation from aerial image data acquisition by a quadcopter type micro unmanned aerial vehicle and a digital still camera. Sensors 12: $453-480$.

38. Sada, P. O. and Omuta, G. E. D. (1979). Auchi Urban Area - A preliminary report On Erosion and Environmental Problems and Planning: In P. O. Sada and G.E.D. Omuta Ifds: Spatial Perspectives in National Development. Proceedings of the 22nd Annual Conference of the Nigerian Geographical Association, Benin Nigeria, 130-152.

39. Smith, H.T.U., (1943): Aerial photographs and Their Application. New York Appleton Century.

40. Tricart J, and Kiewietdeionge C. (1992). Ecogeography and Rural Management - a Contribution to the International Geosphere-Biosphere Programme Harlow, Longman Group: 267.

41. Whiteman A. (1982). Nigeria, its petroleum Geology, Resources and Potentials. 2. Graham and Trotman Publication, 234 - 241. 